\title{
Cry of the earth, of the poor, and of the spirit. Physical, ethical, and spiritual dimensions of the ecological crisis
}

Key words: ecological crisis, climate change, eco-justice, theology of creation.

\section{Summary}

The article offers a comprehensive understanding of the contemporary ecological crisis from a scientific, moral and theological perspective. The physical dimension of the crisis is evident in the host of authoritative warnings from the scientific community in recent years. The crisis is also ethical for the fact that its disproportionate victims are the poor communities who have contributed least to causing the problem in the first place. At a still deeper level, the ecological crisis is also a profoundly spiritual crisis, as it results primarily from our inability to look at the physical world as God's creation, the primordial revelation of divine goodness and glory. The author skilfully weaves together the physical, moral, and religious dimensions of the problem into a unitary whole, and argues that it is only a holistic view of the crisis that can awaken us to the true magnitude of the unprecedented challenge facing our common home.

\section{Introduction}

The contemporary ecological crisis is proving to be one of the most daunting challenges, probably the most arduous that modern humans have ever faced since their evolution as the Homo sapiens. The crisis is about our very home (oikos), the common home of the planet Earth,

1 Università Pontificia Salesiana, Faculty of Philosophy, Piazza Ateneo Salesiano, 1-00139 Roma, Italy, e-mail: joshtromisaac@yahoo.com 
wherein the survival and flourishing of the biotic community, including humanity, is increasingly under threat. It is an eco-logical crisis, having to do with the fate of our very home. In a very insightful way, Pope Benedict XVI summed up this important truth in the Message for the World Day of Peace in 2008 when he said that: "for the human family, this home is the Earth," and that it is "essential to sense that the Earth is our common home" (Pope Benedict XVI 2008) 2 .

Today, we stand in need of nothing short of a paradigm shift in understanding and dealing with the crisis facing our home planet. The fact that the ecological crisis is only getting worse even after decades of study, diagnosis and mitigation efforts means that we have not probably sufficiently understood the malaise in the first place.

Our humble effort in this paper is to propose a wider and a more comprehensive understanding of the crisis facing our common home. We do it by describing the ecological crisis - symbolically as well as in reality - as a triple cry of the Earth, of the poor and of the human spirit. These three cries are attempts to look at the ecological predicament from three different angles - physical, moral and religious - with a view to gain an in-depth and a more complete view of the crisis.

\section{The PHYSICAL dimension of the ecological crisis}

The physical understanding of the crisis is fortunately rather well established, thanks to the tireless efforts of the scientific community in recent years. In the last few decades, a number of international scientific associations and institutions have issued important and direct warnings to humanity about the contemporary ecological crisis. One of the earliest admonitions came in 1992, and was entitled The World Scientists' Warning to Humanity. It was signed by nearly 1,700 of Earth's leading scientists, including 104 Nobel laureates - more than half of the living recipients in the sciences. This declaration was not only a serious warning to humanity but also a clarion call for immediate action in order to avert disaster.

2 The italics in the quotations were added by the author. 
Human beings and the natural world are on a collision course. Human activities inflict harsh and often irreversible damage on the environment and on critical resources. If not checked, many of our current practices put at serious risk the future that we wish for human society and the plant and animal kingdoms, and may so alter the living world that it will be unable to sustain life in the manner that we know....

We the undersigned, senior members of the world's scientific community, hereby warn all humanity of what lies ahead. A great change in our stewardship of the earth and the life on it is required if vast human misery is to be avoided and our global home on this planet is not to be irretrievably mutilated (The World Scientists 1998: 241-250).

More recently, the warnings from the scientific community have been centred around the threat of global warming and associated climate change, one of the most conspicuous facets of the contemporary ecological crisis. Significantly, in the span of last couple of years, some of the most prestigious scientific institutions of the world, including major scientific academies and inter-academies, have taken a clear and unambiguous stand on climate change and related ecological challenges.

In September 2010, the Royal Society, the oldest scientific academy in continuous existence, published an important document entitled Climate Change: a summary of the science. The study, as it is claimed in its introduction, aims to summarise the current scientific evidence on climate change and its drivers, aware that "changes in climate have significant implications for present lives, for future generations and for ecosystems on which humanity depends" (The Royal Society 2010). A month later, in October 2010, the French Academy of Sciences (Académie des sciences) came out with a similar document on the problem of climate change (See Institut de France 2010). The most comprehensive document on climate change by any science academy to date, has been published by the US National Academies of Sciences in 2010, entitled Advancing the Science of Climate Change (The National Academy of Sciences 2010). In May 2011, the Pontifical 
Academy of Sciences published a report on mountain glaciers. The Opening Declaration of this report is worth quoting.

We call on all people and nations to recognise the serious and potentially irreversible impacts of global warming caused by the anthropogenic emissions of greenhouse gases and other pollutants, and by changes in forests, wetlands, grasslands, and other land uses ... aware that we all live in the same home. By acting now, in the spirit of common but differentiated responsibility, we accept our duty to one another and to the stewardship of a planet blessed with the gift of life. We are committed to ensuring that all inhabitants of this planet receive their daily bread, fresh air to breathe and clean water to drink as we are aware that, if we want justice and peace, we must protect the habitat that sustains us (Pontificia Academia Scientiarum 2011).

We may also mention in this regard the most recent 2012 Report from Royal Society entitled People and the Planet which states how "the $21^{\text {st }}$ century is a critical period for people and the planet" and how "human impact on the Earth raises serious concerns" (The Royal Society 2012).

From the avalanche of warnings from the scientific community regarding the disquieting state of our planetary home in recent years we may now pick up two recent and authoritative ones. Both these studies point to how the capacity of the Earth to be a 'common home' for humans and other living beings comes to be increasingly jeopardized.

The first is an important study carried out by a group of 28 scholars associated with the Stockholm Resilience Centre, among them prominent Earth scientists like the Nobel for chemistry Paul Crutzen and James Hansen of NASA. The study which appeared in the September 2009 issue of Nature (Rockström et al. 2009a: 472-475) ${ }^{3}$, seeks to identify and quantify the 'planetary boundaries' that must not be transgressed in order to avoid irreversible ecological damage. In other

3 A more detailed version of the same study came to be published later in Ecology and Society. See: Rockström et al. 2009b. 
words, the proposed planetary boundaries define the safe operating space for humanity with respect to the Earth system and its associated biophysical sub-systems. The authors identify planetary boundaries in nine key areas: climate change, rate of biodiversity loss, interference with the nitrogen and phosphorus cycles, stratospheric ozone depletion, ocean acidification, global freshwater use, change in land use, chemical pollution, and atmospheric aerosol loading. Here is a graphic presentation of the results of the study.

In the diagram above, the inner shading represents the proposed safe operating space for nine planetary systems. According to the study, humanity may soon be approaching the boundaries for global freshwater use, change in land use, ocean acidification and interference with the global phosphorous cycle. The most alarming conclusion of the report was that with regard to the areas of climate change, rate of biodiversity loss and interference with the nitrogen cycle, humanity has already transgressed the limits.

Fig. 1. Planetary Boundaries (Rockström et al. 2009a: 472)

The boundaries in three systems (rate of biodiversity loss, climate change and human interference with the nitrogen cycle), have already been exceeded.

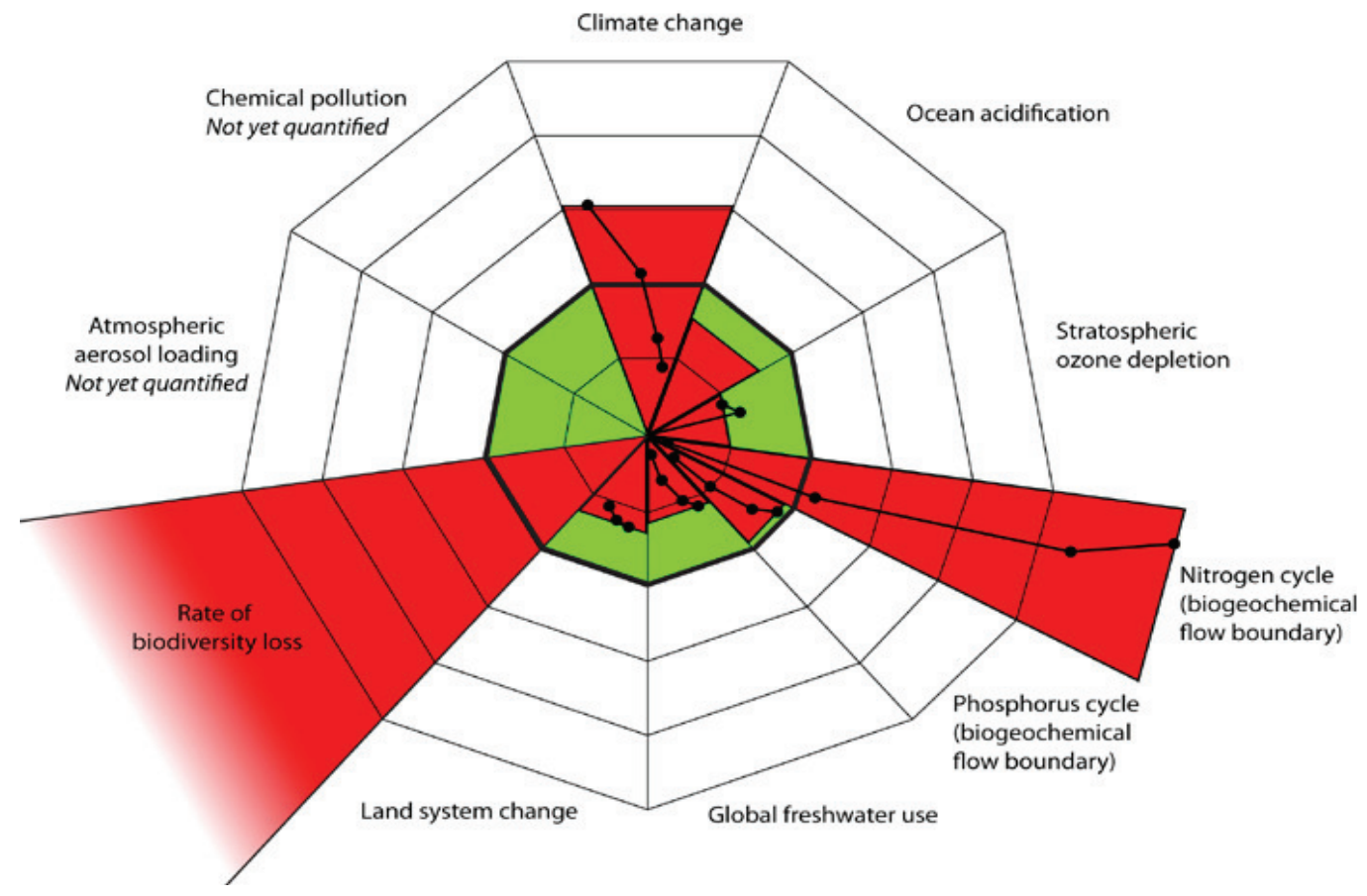


The study on the planetary boundaries conveys a very important message, namely, that it is the entire common home of humanity that is threatened. The contemporary ecological crisis in this regard is unique in the sense that it is not about a single environmental problem, like climate change, for example - as it is often presented in the public media. The concept of the planetary boundaries instead demonstrates how the Earth system is a single, integrated complex system, with many inter-related and inter-dependent sub-systems. It is the global home of the Earth that is in peril. The contemporary ecological crisis in this regard is unparalleled in the geological history of the planet. It is the first time that humanity's own dwelling is threatened in such a comprehensive way.

A second authoritative warning regarding the ecological threat facing our planetary home have been made by the Intergovernmental Panel on Climate Change (IPCC) which draws on the work of nearly 2,500 scientists from nearly 130 nations. We quote here from the most recent report from the IPCC, namely, the Fifth Assessment Report, of which the Summary for Policy Makers was released on $30^{\text {th }}$ September 2013.

Warming of the climate system is unequivocal, and since the 1950s, many of the observed changes are unprecedented over decades to millennia. The atmosphere and ocean have warmed, the amounts of snow and ice have diminished, sea level has risen, and the concentrations of greenhouse gases have increased.... Each of the last three decades has been successively warmer at the Earth's surface than any preceding decade since 1850 (Stocker et al. 2013: 4-5).

According to the report almost the entire globe has experienced surface warming in the recent decades as global average surface temperature increased by $0.85^{\circ} \mathrm{C}$ during the period $1880-2012$ (Stocker et al. 2013: 5). The report predicts that the global temperatures are likely to rise by $0.3^{\circ} \mathrm{C}$ to $4.8^{\circ} \mathrm{C}$, by the end of the century depending 
on possible carbon emission scenarios (Stocker et al. 2013: 20) ${ }^{4}$. It is important to recall here that global average temperature variations have never exceeded $1^{\circ} \mathrm{C}$ since the beginning of the present human civilization! It may also be recalled that the 2007 IPCC report had warned that up to 30 per cent of plant and animal species so far assessed are likely to be at increased risk of extinction if increases in global average temperatures exceed $1.5-2.5^{\circ} \mathrm{C}$ (Pachauri, Reisinger 2007: 48).

While continuing to caution humanity about the precarious state of our home planet, a constant preoccupation of the scientific community in recent years has been about the risk of crossing the thresholds in tampering with the Earth's climate and its natural processes. Scientists fear that the current state of the planet could be destabilized if human activity causes critical thresholds to be passed. Such a concern is expressed through the concept of 'tipping points'. A tipping point commonly refers to a critical threshold at which a tiny perturbation can have large, long-term consequences for the planet's natural systems. Many scientists now hold that "human activities may have the potential to push components of the Earth system past critical states into qualitatively different modes of operation, implying large-scale impacts on human and ecological systems" (Lenton, et al 2008: 1786).

As Lynn White noted already in 1967 in his epoch-making article: "surely no creature other than man has ever managed to foul its nest in such short order" (White 1967: 1204).

\section{The ETHICAL dimension of the ecological crisis}

The ecological crisis is not only a physical problem, it is also a human tragedy of unimaginable proportions which threatens security and livelihoods of people around the world. The ecological crisis is a profoundly 'moral' crisis as Pope John Paul II had noted already in 1990 (Pope John Paul II 1990). It is about the 'ethical' dimension of the contemporary ecological crisis that we shall be dealing in this

4 The Arctic region will warm more rapidly than the global mean. 
section. The discussion on ecological questions today has certainly gone beyond concern for polar bears and exotic pandas to include matters of equity, justice, solidarity with the poor and vulnerable, and responsibility towards future generations, etc.

The 'human' face of the contemporary ecological crisis is most evident when we examine its impact on basic areas of human welfare like nutrition, health and shelter. Food and health security, along with safe shelter are fundamental necessities for human flourishing and survival. The current scenario with regard to global food security presents a stark challenge with nearly a billion people already hungry and other two billion chronically undernourished. The impending ecological crisis, with its various manifestations ranging from land degradation to water scarcity and biodiversity loss, will further compound the precarious situation of food security at the global level. However, it is climate change that will have most pronounced impact on agriculture in the decades to come, with reverberating effects on food security. The impact of climate change on food security will be felt disproportionately in the various parts of the globe, especially in the most vulnerable regions of Sub-Saharan Africa and South-East Asia.

The sad paradox about the contemporary ecological crisis is that it is caused mainly by the rich minority, but whose early, innocent and disproportionate victims are the poor and vulnerable members of our common family. On the one hand, the analysis of the ecological footprint of the consumption of natural resources and the carbon footprint of nations and individuals - both of which are empirically measurable - points to how it is the rich world that has mostly contributed to create the contemporary ecological crisis. On the other hand, it is becoming increasingly clear that the most devastating effects of the crisis, ranging from extreme weather calamities to malnutrition and diseases, will fall mainly on the poor who have contributed least to the precarious situation of our common home.

The contemporary ecological crisis becomes an epitome of injustice on account of the tragic truth that is caused largely by the rich and affluent but its disproportionate victims are the poor and vulnerable. 
Even today, rich countries like the USA, Canada, those in Western Europe, Japan, Australia, etc. contribute many times the greenhouse gases per capita as poor countries but will face much less of the fallout. In contrast, it is the poorest countries and most vulnerable citizens who will suffer the earliest and most damaging setbacks from impacts of contemporary ecological crisis - from pollution to increased exposure to droughts, floods, storms, and sea-level rise (Sze, London 2008: 1342-1343).

The carbon footprint of the world's poorest 1 billion people is about $3 \%$ of the world's total carbon footprint (United Nations Development Programme 2007: 43). However, these populations will be most affected by the contemporary ecological crisis. While the ecological crisis affects our common home and its common household, its deleterious impacts will befall mainly on the poor and the most vulnerable sections of our society. The debate over climate change is often dominated by technical issues of carbon credits and emissions targets. But it is important to put people at the centre while talking about the ecological crisis, and precisely the poor who are worst affected by it.

Robert Henson expresses well the tragic irony of an ecological problem like climate change that will affect most the poor who have least contributed to its underlying causes.

If all that global warming did was to make life a bit steamier for the people who consume the most fossil fuels, then there'd be a karmic neatness to it. Alas, climate change doesn't keep its multitude of effects so nicely focused. A warming planet is liable to produce a cascade of repercussions for millions of people who have never started up a car or taken a cross-country flight (Henson 2006: 139).

It is precisely the poor who will have to a pay a disproportionately high price for the contemporary ecological crisis, though they have contributed so little to cause it. According to the 2007/08 Human Development Report the poor with no responsibility for the ecological debt will face the most immediate and severe human costs. 
The world's poor will suffer the earliest and most damaging impacts. Rich nations and their citizens account for the overwhelming bulk of the greenhouse gases locked in the Earth's atmosphere. But, poor countries and their citizens will pay the highest price for climate change (United Nations Development Programme 2007: 3).

As Jamie Hosking and others note, it is precisely this 'mismatch' between the benefits and harms of emissions that renders the contemporary ecological crisis a key global justice issue (Hosking, et al. 2011: 494). The great ethical tragedy about the contemporary ecological crisis is that a large majority of the members of our common household suffer on account of the greedy actions of a minority. As denounced by the Brazilian Archbishop Helder Camara, the ecological crisis is caused because "greedy or thoughtless people destroy what belongs to all" (Camara 2008: 7).

The gross injustices that lie at the root of the contemporary ecological crisis contribute to the brewing of a sort of 'ecological' apartheid between the poor and rich in our globalized world. The injustices leading to a divided world are especially evident in the ecological and carbon footprints of individuals and communities on our common home planet and on its atmosphere. While the carbon footprint analysis indicates the huge disparities between nations in the emissions of greenhouse gases that lead to global warming and cause climate change, the ecological footprint analysis reveals profound inequalities in the consumption of the natural resources. In fact, through a study of these two mechanisms it is possible to quantify and empirically measure the unjust divide that exists between countries and between individual citizens in the appropriation of our home planet's resources and its common atmosphere.

It should also be remembered that disproportionate impacts are ultimately unsustainable for the carrying capacity of our home planet's atmosphere. If every person living in the developing world had the same carbon footprint as the average for high income countries, we would require the atmospheres of six planets. With a global per capita carbon footprint at Australian levels, we would need seven 
planets, and with per capita footprint of Canada and United States we would require the atmospheres of nine planets! (United Nations Development Programme 2007: 48).

Fig. 2. The Disproportionate Impacts of Climate Change in terms of Mortality (Patz, et al. 2007: 400)
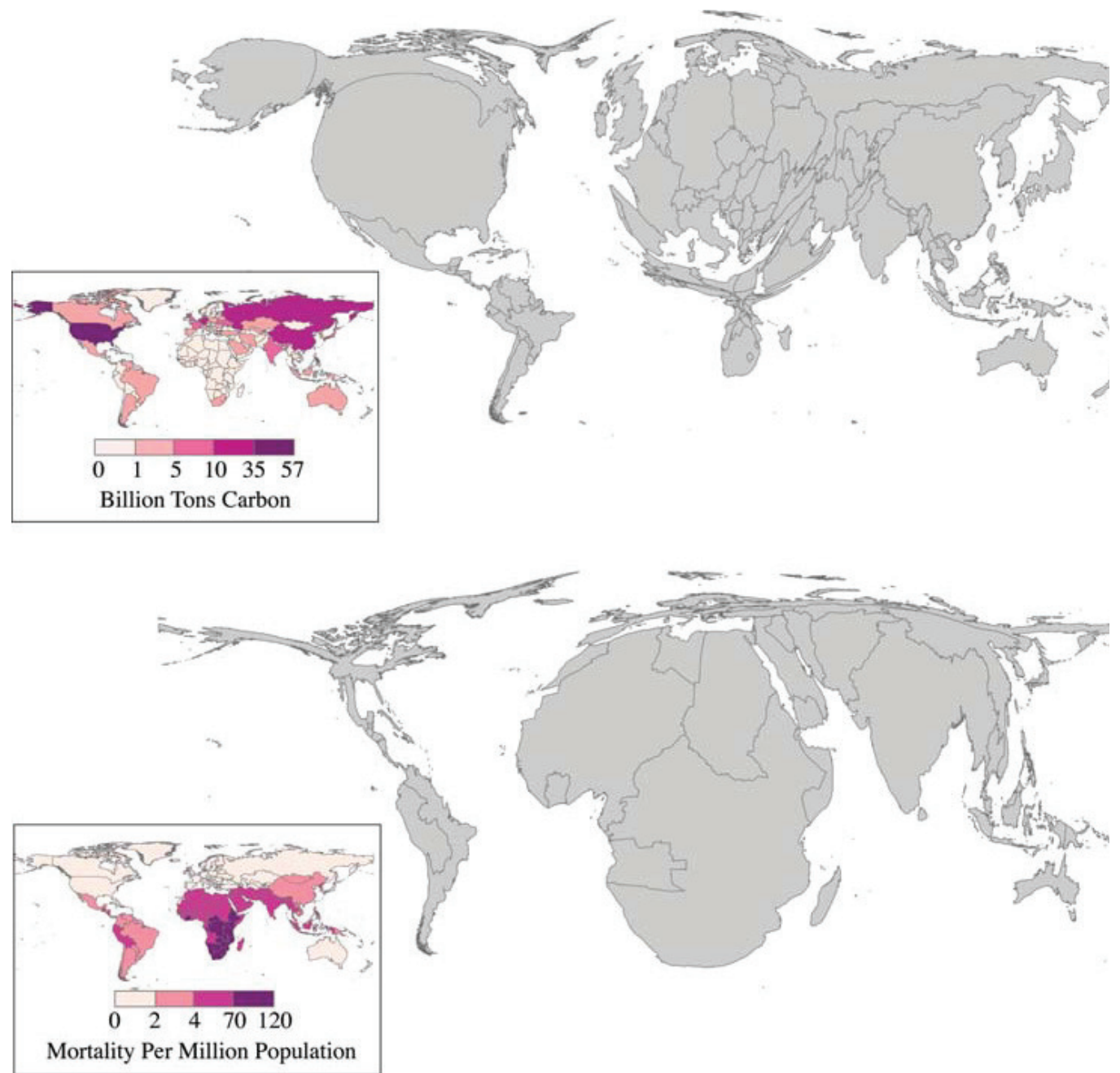

The ecological apartheid between the rich and the poor is clearly evident when one considers the impacts of the crisis. Nearly 99 percent of the casualties of climate change now are in developing countries (Oxfam 2009: 24). The above map expresses very well the 'apartheid' in terms of the stark contrast between the high emitters of greenhouse 
gases (the top section) and those who will suffer most on account of the same emissions (the down section).

As evident from the above map, humanity is indeed drifting into a real 'climate apartheid' when it comes to the emissions of greenhouse gases and the consequent impacts of it on human welfare.

\section{The SPIRITUAL dimension of the ecological crisis}

The ecological crisis is not merely about the collapse of the planet's ecosystems and biochemical cycles with a profound impact on human populations, especially on the poor, as it has so far been evidenced. The ecological crisis is also a deeply spiritual and religious crisis. The crisis is only an externalization of a deeper inner malaise. As Seyyed Hossein Nasr noted decades ago, "the blight wrought upon the environment is in reality an externalization of the destitution of the inner state of the soul of that humanity whose actions are responsible for the ecological crisis" (Nasr 1990: 3). In a similar vein, Pope Benedict XVI pointed out, with a ring of prophecy, in the homily at the inaugural mass of his pontificate in 2005, "the external deserts in the world are growing, because the internal deserts have become so vast" ( Pope Benedict XVI 2005). The ecological crisis is, in fact, symptomatic of a deeper spiritual and religious crisis.

The spiritual dimension of the contemporary ecological crisis is still to be recognized in an adequate manner, by the very religions and faith communities. Churches and religions have lagged far behind in acknowledging the underlying spiritual dimension of the crisis. For most faiths and religious groups, the ecological crisis still remains a host of environmental problems, and not the crisis of our common home, where God co-dwells with humanity. It appears that the religions and churches are still to wake up to the magnitude of the contemporary ecological crisis, which is ultimately a crisis facing God's very creation.

First of all, the ecological crisis points to our anamnesis (forgetfulness) of the fundamental truth about the physical world as creation. For the believers, the material world is not just a surrounding 
'environment' or even just 'nature' as in the physical sciences. For them, the world is above all, God's marvellous handiwork. It is creation. It is the result of God's free creative act, an outpouring of his self-giving and self-revealing love. As such creation has an intrinsic goodness, beauty and integrity, independent of human perception and utility.

Creation is an act of God's love, realized in total freedom. Our physical universe is not an accident, or a fluke event, as it is sometimes presumed in the secular thought and culture. The whole of creation and every creature is a sign of God's outpouring love. "In contrast to the violent beginning motifs of pagan cosmogonies, the Bible depicts creation as the tender loving act of a gracious God" (Young 1994: 85). Every creature is brought into existence out of love and with a definite purpose. God's self-sharing love is what animates every creature. Every bit of creation and every creature is precious precisely because God loves all of His creation. As the medieval mystic Hildegard of Bingen has so beautifully expressed, the entire creation has been embraced by God's loving kiss.

As the Creator loves His creation

so Creation loves the Creator.

Creation, of course, was fashioned

to be adorned, to be showered,

to be gifted with the love of the Creator.

The entire world has been embraced by this kiss

(Hildegard of Bingen 1982).

Earth, our home planet, is thus the gift of a loving Creator, clasped intimately in His loving embrace. "God so loved the world" ( $J n$ 3:16), says Jesus in the gospel of John. The world here is the cosmos in the Greek original, and not just humanity, but the entire world. It is the fundamental truth of having been created by God in love which renders creation, including Earth, our home planet, intrinsically good. As it is commonly known, the biblical word good, tob in Hebrew, has different layers of meaning. The word can mean good, beautiful, joyous, pleasing, desirable, usable, suitable, lovely, friendly, kind, etc. 
The intrinsic sanctity of God's creation ultimately derives from the fact that it is infused with the divine presence and is inhabited by God: by the in-dwelling Spirit of God and the co-dwelling of the Word incarnate. Our creation is thus holy ground. "Our feet are on holy ground - ground so holy that Moses took off his shoes" (Morton 1993: 125). God's presence in creation renders it sacred, and reveals how the entire physical universe, and our home planet in particular where the supreme event of Incarnation took place, is God's own home. Creation is not simply a 'work of God's hands', it is God's own oikos (house).

The contemporary ecological crisis, it appears, arises precisely from our inability to perceive the physical world as God's creation, to love it as the Creator does, to respect its integrity, and to appreciate its intrinsic goodness and beauty, beyond mere considerations of utility and consumption. The human activities that contribute to the ecological crisis are indeed 'crimes against creation', to use an expression found in the 1990 joint appeal of the scientific community (Sagan 1990: 615). The degradation of our home planet is a destruction of God's creation, and constitutes nothing less than a disrespect toward the Creator.

In second place, the contemporary ecological crisis points to our profound spiritual blindness to the great book of God's creation, and our incapacity to look at and respect the physical world as a divine symbol and sacrament. Our physical world is also God's primary revelation. Creation is, as the early Fathers loved to call it, God's 'book of works' that reveals His nature and character. Creation is, in this regard, a living symbol and a true icon of God. Created objects are indeed sacraments which render God's invisible presence in creation tangibly real in time and space.

Creation is, indeed, the very first epiphany of God. Some of the early Fathers of the Church, like John Chrysostom, spoke of the two Books of God: the Book of Works and the Book of Words; the book of the creatures and the book of the scriptures. The book of Works is precisely the creation, the entire physical universe. God's book of works is all the more our home planet Earth with its unique and rich biosphere and infinite diversity of life forms. The book of Works has 
been God's first and primordial revelation, and has not been substituted or cancelled by the second book of the Words. Instead, the two books need to be read together to have a complete understanding of God. As John Scotus Eriugena says: "Christ wears 'two shoes' in the world: Scripture and nature. Both are necessary to understand the Lord, and at no stage can creation be seen as a separation of things from God" (Sleeth 2008: 101).

The perception of the physical world as the self-revelation of God is deeply rooted in Christian tradition. The following words of St. Augustine are very clear in this regard:

Some people, in order to discover God, read books. But there is a great book: the very appearance of created things. Look above you! Look below you! Read it. God, whom you want to discover, never wrote that book with ink. Instead, He set before your eyes the things that He had made. Can you ask for a louder voice than that? (Augustine, De Civitate Dei, Book 16).

The tradition of looking at the physical world as God's book of works and a visible manifestation of the super-eminently bountiful Creator was carried on into the medieval period. Bonaventure spoke of the physical universe as "a book reflecting, representing and describing its Maker, the Trinity" (Bonaventure, Breviloquium 2.11-12).

The belief of creation as the primordial revelation of God was not lost even in the Reformation traditions, in spite of their great emphasis on the written scriptures. For Martin Luther, "God writes the Gospel not in the Bible alone, but also on trees, and in the flowers and clouds and stars" (Sleeth 2008: 103). And John Calvin adds: "The creation is quite like a spacious and splendid house, provided and filled with the most exquisite and the most abundant furnishings. Everything in it tells us of God" (Calvin 1845-1846: 1:14). The limpidity of the perception of the physical world as God's book of works, capable of uplifting the hearts of the believers to the Creator, is best evident in the following passage from Thérèse of Lisieux: 
Jesus set before me the book of nature. I understood how all the flowers He has created are beautiful, how the splendour of the rose and whiteness of the lily do not take away the perfume of the little violet or the delightful simplicity of the daisy.

With enraptured gaze we beheld the white moon rising quietly behind the tall trees, the silvery rays it was casting upon sleeping nature, the bright stars twinkling in the deep skies, the light breath of the evening breeze making the snowy clouds float easily along; all this raised our souls to heaven (Sleeth 2008: 108).

In its capacity to point to the Creator, creation and all created realities perform a 'symbolic' function. They are symbols of God. As the Greek etymology of the word goes, a 'symbol' attempts to place together (sum + ballein) various fragments for a more profound understanding of reality. Creation as a symbol brings together the finite and the infinite, the natural and the supernatural. Creation's value lies precisely in its symbolism, in its capacity to link the finite with the infinite. From a theological perspective, every created reality is a symbol, a sign-post, that points beyond itself to the Creator. Creation thus symbolically represents the Creator, often in silence which is the cherished language of symbols. The Earth speaks in the eloquent silence of hills and trees. Enraptured by such symbolic eloquence, the Indian poet Rabindranath Tagore said, "Silence, my soul, these trees are prayers."

As symbols of God, created realities are vestigia Dei, signs and traces of God's presence in creation. Such a profound awareness permeated medieval Christian world view and cosmology. For the medieval society, "every living form of plant, bird or animal, the sun, moon and stars, the waters and the mountains, were seen as signs of things sacred (signa rei sacrae), expressions of a divine cosmology, symbols linking the visible and the invisible, earth and heaven" (Sherrard 1987: 64). For the medieval mystic, Meister Eckhart, "every creature is a book about God," and "so full of God is every creature" (Meister Eckhart, Sermons). As St John of the Cross says, "the creatures are, 
as it were, a trace of the passing of God, whereby are revealed His greatness, power, wisdom, and other Divine virtues" (Peers 1953: 48).

The contemporary ecological crisis is, at a deeper level, a consequence of our blindness to God's self-revelation in creation, of our inability to perceive the physical world as a symbol, icon and sacrament of the Creator. "We have broken the sacred covenant, the symbolic connection between ourselves and our world. By disconnecting this world from heaven, we have in fact desacralized both" (Chryssavgis 2009: 22). The danger today, it appears, is not so much falling into pantheism: equating creation and created entities with God. The risk appears to be just the opposite. Our problem is precisely a lack of respect for matter (see: Derick 1972: 88). Consequently, creation is thus no more a symbol for us of the divine Creator. Instead our consumerist culture has erected the idols of materialism, while reducing the physical world to a heap of material resources and products, to be consumed and thrown away.

The various manifestations of the ecological crisis also point to how we are diminishing the capacity of created goods to be limpid and eloquent symbols of God's presence in creation. In a polluted world, created things are no longer 'symbols' of God! The polluted skies and streams cannot speak eloquently of the glory of God, and fail to reveal His infinite goodness. The infinitely diverse living species are indeed pages of God's great Book of Works, revealing the Creator's wisdom and goodness. The current spasm of extinction of species amounts to nothing less than tearing away pages from God's grand book of revelation which is the physical world. Many species are indeed being forced into extinction, and at alarming rates too. "This can only be an affront to a God who delights in creatures in all their diversity and specificity" (Edwards 2006: 76). When we allow creation to be degraded and damaged, therefore, we lose our sense of God's very self (Catholic Bishops of England Wales 2002: 4). "If the sun is hazy or blocked by smog, if the water is unclean, the air poisonous, the wind full of dust and smoke, the soil eroded or desiccated, and biological diversity consumed by the fires burning up the rain forests, 
the sacramental 'light' of nature grows dim. To degrade the earth is to interfere with the message of its Creator" (Toolan 2001: 37).

The contemporary ecological crisis is thus a deeply spiritual crisis. Instead of letting the physical world be a 'symbol' of the revelation of God's grandeur and goodness, our 'diabolic' life styles that devastate our home planet, appear to contribute to wedge a 'separation' of creation from the very Creator. The ecological crisis is indeed "about the future of God's creation," (United States Conference of Catholic Bishops 2001:1) as much as about the future of our common home and household.

\section{Conclusion}

As we have argued in this paper, it is important to look at the contemporary ecological scene from a triple perspective - physical, moral and theological - in order to gain a more complete understanding of the crisis. Only such a holistic perspective can offer a total view of our ecological predicament, commensurate with the magnitude of the challenges ahead of us.

In order to respond to the triple cry of the Earth, of the poor and of the spirit, we stand in need a triple conversion as exemplified by the life of St. Francis of Assisi. In the wake of the contemporary ecological crisis, what is needed is a new vision and a life-style that embrace all of the three sides of the relational triangle of reality. To quote PeterHans Kolvenbach we need: not "an anthropocentrism independent of God and the environment, a theocentrism that pretends to ignore creatures and all created things, a biocentrism that would ignore the Creator and the call to collaborate with him in relationship with the environment" (Kolvenbach 1998). We need to weave together the cosmic, human and divine strands of reality into a seamless fabric. We are called to dwell in the common home of the Earth in harmony with all our fellow creatures in cosmic fellowship, in harmony with our fellow human beings in fraternal solidarity, and in harmony with God, the Creator, in creaturely dependence. 
We will succeed in saving our common home, when we will realize that we have not only a common Father in heaven, but also a common Mother Earth, to be loved and cared for. Such spiritual paternity and earthly maternity alone can bring about true fraternity among humanity.

\section{References}

Augustine, De Civitate Dei, Book 16.

Bonaventure, Breviloquium 2.11-12.

Calvin J., 1845-1846, Institutes 1:14.

Camara H., 2008, Sister Earth: Creation, Ecology and the Spirit, New York, New City Press.

Catholic Bishops of England Wales, 2004, The Call of Creation: God's Invitation and the Human Response.

Chryssavgis J. (ed.), 2009, Cosmic Grace Humble Prayer: The Ecological Vision of the Green Patriarch Bartholomew, Grand Rapids, MI Cambridge, UK, William B. Eerdmans.

Derrick C., 1972, The Delicate Creation: Towards a Theology of the Environment, London, Tom Stacey Ltd.

Edwards D., 2006, Ecology at the Heart of Faith, Maryknoll, NY, Orbis Books.

Henson R., 2006, The Rough Guide to Climate Change, London, Rough Guides Ltd.

Hildegard of Bingen, 1982, Meditations with Hildegard of Bingen, (trans. Uhlein G.), Santa Fe, NM, Bear.

Hosking J., Jones R., Percival T., Turner N., Ameratunga S., 2011, Climate Change: The Implications for Child Health in Australasia, Journal of Pediatrics and Child Health 47(8), 493-496.

Institut de France, Académie des sciences, Le changement climatique (26 October 2010).

Kolvenbach P.H., 1998, Our Responsibility for God's Creation - Address at Opening of Arrupe College, Jesuit School of Philosophy and Humanities, Harare / Zimbabwe (22 August 1998). 
Lenton T. M., Held H., Kriegler E., Hall J. W., Lucht W., Rahmstorf S., Schellnhube H. J., 2008, Tipping Elements in the Earth's Climate System, Proceedings of the National Academy of Sciences, vol. 105, no 6, 1786-1793.

Meister Eckhart, Sermons.

Morton J. P., 1993, Environment and Religion: The Evolution of a New Vision, in: Hull F. (eds.), "Earth \& Spirit: The Spiritual Dimension of the Environmental Crisis", New York, Continuum, 119-133.

Nasr S. H., 1990, Man and Nature: The Spiritual Crisis of Modern Man, London - Boston, Unwin Paperbacks.

Oxfam, 2009, Suffering the Science: Climate Change, People, and Poverty, Oxfam Briefing Paper, 6 July 2009.

Pachauri R. K., Reisinger A. (eds.), 2007, Intergovernmental Panel on Climate Change, Climate Change 2007: Synthesis Report. Contribution of Working Group I, II and III to the Fourth Assessment Report of the Intergovernmental Panel on Climate Change, Geneva: IPCC.

Patz J. A., Gibbs H. K., Foley J. A., Rogers J. V., Smith K. R., 2007, Climate Change and Global Health: Quantifying a Growing Ethical Crisis, EcoHealth 4(4), 397-405.

Peers E. A. (ed. and trans.), 1953, The Complete Works of St John of the Cross (vol. II), Westminster, MD, Newman Press.

Pontificia Academia Scientiarum, 2011, Fate of Mountain Glaciers in the Anthropocene: A Report by the Working Group Commissioned by the Pontifical Academy of Sciences (5 May 2011).

Pope Benedict XVI, 2008, The Human Family, A Community of Peace (Message for the for the World Day of Peace, 1 January 2008).

Pope Benedict XVI, 2005, Homily at the Inaugural Mass of Pontificate (24 April 2005).

Pope John Paul II, 1990, Peace with God the Creator, Peace with All of Creation (Message for the World Day of Peace, 1 January 1990). Rockström J., et al., 2009a, A Safe Operating Space for Humanity, Nature 461 (24 September 2009), 472-475. 
Rockström J., et al., 2009b, Planetary Boundaries: Exploring the Safe Operating Space for Humanity, Ecology and Society 14(2), 32ff. (http://www.ecologyandsociety.org/vol14/iss2/art32/)

Sagan C., 1990, Preserving and Cherishing the Earth - An Appeal for Joint Commitment in Science and Religion, American Journal of Physics, 58, 615.

Sherrard P., 1987, The Rape of Man and Nature: An Enquiry into the Origins and Consequences of Modern Science, Suffolk, Golgonooza Press.

Sleeth J. M., 2008, Teachings on Creation through the Ages in: Maudlin, M. G., Baer M. (eds.), The Green Bible. New Revised Standard Version London, Harper Collins, 98-115.

Stocker T. F., Qin D., Plattner G.-K., Tignor M., Allen S. K., Boschung J., Nauels A., Xia Y., Bex V., Midgley P. M. (eds.), 2013, Intergovernmental Panel on Climate Change, Climate Change 2013: The Physical Science Basis. Contribution of Working Group I to the Fifth Assessment Report of the Intergovernmental Panel on Climate Change, Cambridge - New York: Cambridge University Press.

Sze J., London J. K., 2008, Environmental Justice at the Crossroads, Sociology Compass, 2/4, 1331-1354.

The National Academy of Sciences, 2010, Advancing the Science of Climate Change, Washington, D.C: The National Academies Press. The Royal Society, 2010, Climate Change: A Summary of the Science (September 2010).

The Royal Society, 2012, People and the Planet (April 2012).

The World Scientists' Warning to Humanity, 1998, in: Ehrlich P., Ehrlich A., (eds), "Betrayal of Science and Reason: How AntiEnvironmental Rhetoric Threatens Our Future", Washington, D.C.: Island Press, 241-50.

Toolan D., 2001, At Home in the Cosmos, Maryknol, NY, Orbis Books. United States Conference of Catholic Bishops, 2001, Global Climate Change: A Plea for Dialogue, Prudence, and the Common Good, Washington, D.C., USCCB. 
United Nations Development Programme, 2007, Human Development Report 2007/2008. Facing Climate Change: Human Solidarity in a Divided World, New York, Macmillan.

White L., 1967, The Historical Roots of Our Ecologic Crisis, Science, vol. 155, 1203-1207.

Young R. A., 1994, Healing the Earth: A Theocentric Perspective on Environmental Problems and Other Solutions, Nashville-Tennessee, Broadman \& Holman Publishers. 